\title{
Corporate social responsibility in the Mexican oil industry: Social impact assessment as a tool for local development
}

\author{
Armando García-Chiang
}

\begin{abstract}
Mexico's 2008 energy reform established that Petróleos Mexicanos and its subsidiary entities could contract with individuals or corporate entities for labor and the provision of required services to improve the implementation of its activities. The reform has allowed private companies to become more involved in the process of oil extraction and to implement Integrated Petroleum Exploitation Contracts. This participation of the private sector has brought with it the need to evaluate its activities' social and environmental impact on the territory. One of these evaluations' main objectives is to project Corporate Social Responsibility schemes. We can see from experience that it is possible for private oil companies' participation in CSR schemes to contribute to local development, but the application of CSR actions does not in itself imply an impact on local development. This article aims to show the case of a pioneering experience in Mexico concerning the link between academics and the segment of oil companies that try to assess their activities' social impact and implement Corporate Social Responsibility schemes under federal regulations. In order to achieve it, a work team belonging to Universidad Autónoma Metropolitana has developed a methodology that uses quantitative and qualitative data. The main results of this case study show us that it is necessary to develop appropriate approximation and assessment methodologies for implementing Corporate Social Responsibility actions in each territory in order to stimulate local development. Moreover, there are two essential conditions for actually achieving results for local development by investing in communities within the context of CSR actions in oil-production regions. The first of these conditions is a 'territorialization' of the proposals, and the second is the creation of different types of CSR actions. These last two conclusions are also challenges that Mexico's fledgling private oil sector will have to solve in the very near future with the objective of improving its relations within the social and environmental context where it carries out its activities.
\end{abstract}

Keywords: CSR, Social impact Assesment, Territorialization, Local development, Mexico, Oil industry

\section{Introduction}

Over the past two decades, the development of Corporate Social Responsibility (CSR) in Mexico has been closely linked to several initiatives within the business sector. Organizations first started to engage in CSR in the 1990s. Integrating CSR became a central business objective even in its early stages. This is why these organizations have developed and implemented numerous strategies for promoting and encouraging that CSR models be integrated into the functional schematics of

Correspondence: agch@xanum.uam.mx

Department of Sociology, Universidad Autónoma Metropolitana, San Rafael Atlixco, 186, Colonia Vicentina, Delegación Iztapalapa, D.F. Edificio H-163, 04930 Mexico City, CP, Mexico most businesses in Mexico from its largest companies to Small and Medium-Sized Enterprises (SMEs).

In parallel, the development of CSR's operational concept (Garriga and Melé 2004) in Mexico has been closely linked to the same group of private sector organizations that have been involved in its promotion since the 1980s. In fact, there has been a close relationship between Mexico's business sector and CSR development (Pérez 2009). However, in the past few years, both national and international contexts have been crucial for incorporating new actors into the social and environmental responsibility debate. While large parastatal companies are among these new actors, there are also civil society organizations that have expressed their concern 
about private and state sectors' impacts on human rights, the environment, and indigenous peoples as well as on gender and anti-corruption issues.

The result of this approach among emerging actors has reflected compelling progress regarding agreements signed with international organizations, mainly through bilateral cooperation in the field of CSR. Likewise, political statements have been made and initiatives have been pursued that involve legislative action in Mexico. Furthermore, agencies have been established for the specific purpose of developing CSR in the country. Among their efforts, these agreements focus on both parastatal and private companies, especially those in the energy industry, like oil companies, which have significant impacts on the territory where they carry out their activities. In many countries, these impacts have resulted in ethics requirements for the oil industry, and Mexico is no exception.

Oil companies seem to continue to act on principles of minimizing impact and, supposedly, reversing the effects of the oil industry (Flores 2009; Frynas 2009). These kinds of industries in Mexico are supposedly bound by CSR policies, but they are still far from truly implementing them on the ground. The key would be to apply CSR schemes holistically. That is, their scope of action should begin within companies to later be extended to the agents and the environments among which the business activities generate an impact. Corporate Social Responsibility should not be pursued in vain. Instead, the company ought to integrate social and environmental concerns in its business operations voluntarily by promoting a sustainable relationship with all stakeholders that are impacted by the company's activity.

This article aims to present a pioneering experience of the link between academics and the segment of oil companies that try to assess the social impact of their activities and implement CSR schemes under federal regulations in Mexico. It addresses the case of a workgroup that is part of Universidad Autónoma Metropolitana in Mexico City. This group has developed a methodology for using a territorial approach, assessing social impact, and implementing CSR actions for the oil industry as regulated by the Mexican government. Accordingly, it describes the development of a methodology that uses quantitative and qualitative data.

The article also aims to demonstrate that there are two essential conditions that CSR actions must have in order to result in the local development of regions where oil is exploited, they are: 'territorialization' of the proposals and the creation of different types of CSR actions. The case that is presented will show that it is necessary to develop an appropriate approach and assessment methodologies for implementing CSR actions in each territory in order to stimulate local development.

\section{Case description}

Mexico's largest oil company is Petróleos Mexicanos (PEMEX), a state-owned public company incorporated as an independent agency of the federal government, which was established by a decree passed on June 7 , 1938. Its fundamental objective is to centrally and strategically manage the oil industry's activities in Mexico. PEMEX is a significant generator of economic resources, jobs, and opportunities for national development. It has been a critical player in boosting the country's economic growth and industrial development since the second half of the 1970s (Grayson 1980).

Internally, this parastatal company is made up of four subsidiary bodies. Of these four, PEMEX Exploration and Production (PEP) centers on extraction and carries out the exploration, production, processing, and marketing of crude oil and natural gas in both domestic and foreign markets. It is divided into four operating regions: North, South, Northeast Marine (RMNE, for its Spanish acronym), and South Marine (RMSE, for its Spanish acronym).

In 1996, after some serious accidents took place in its facilities, PEMEX PEP sought to implement stringent security and environmental protection practices that aimed to identify the strengths and weaknesses of its security management. To achieve this, the Corporate Industrial Safety and Environmental Protection Division was created to develop and implement management systems in order to carry out safer and more environmentally friendly operations and incorporate best practices (Petróleos Mexicanos 2002).

In 2006, PEMEX developed a new model for sustainable development, which is part of its corporate strategy (Pemex Exploration and Production: Systems report, unpublished). The model's objectives were to comply with environmental regulations, avoid environmental risks even in the absence of regulation, and ensure the viability and sustainability of business development plans, thus devising the future implementation of CSR guidelines (Petróleos Mexicanos 2006). Since joining the Global Reporting Initiative (GRI) and the Global Pact, PEMEX has sought to reconcile its business interests with the values and demands of civil society in areas related to human rights, labor rights, the environment, and anti-corruption (García-Chiang and Rodríguez 2008).

In the 2010-2025 PEMEX Business Plan, CSR was defined as one of the four lines of action for addressing its 23 major business challenges. The company seeks to use CSR to improve its image and relationships with stakeholders and incorporate environmental protection and social responsibility as key elements of its operation. Also, in External Affairs ( $A E$, for its Spanish acronym) documents and annexes to contracts, PEMEX defines CSR as the willingness of companies to integrate policies, programs, and practices beyond their legal obligations, thus contributing to the sustainable development of society and improving the quality of life for individuals and their families. 
Mexico's 2008 energy reform focused on reforming the regulatory law of Article 27 of the national constitution to establish that PEMEX and its subsidiary entities could contract with individuals or corporate entities for labor and the provision of required services to improve the implementation of its activities. This was made known to other oil operators in the Mexican context, some of which already had contracts with Pemex. It was a new step forward regarding CSR.

This reform has allowed private companies to become more involved in the process of oil extraction and to implement Integrated Petroleum Exploitation Contracts (CIEP, for its Spanish acronym), which are overseen by the Secretariat of Energy and the National Hydrocarbons Commission (Comisión Nacional de Hidrocarburos, CNH). When the reform went into effect, social baseline studies became Social Impact Assessments (Dauzacker 2007) that met international standards. Moreover, CSR plans turned into Social Management Systems. At this point, we can see from experience that it is possible for private oil companies' participation in CSR schemes to contribute to local development, but the application of CSR actions does not in itself imply an impact on local development.

In 2012, Pemex Exploration and Production (PEP) launched the first round of bidding for its Integrated Oil Exploration Contracts. The interest generated by this process among firms in the industry, both domestic and foreign, was reflected in 27 operator and service companies purchasing over 50 bidding packages in the three contractual areas (Pemex Exploración y Producción 2012). As a result of this process, private companies entered as Pemex partners to exploit fields in Tabasco. British companies, like Petrofac Facilities Ltd., won this round. This company, in particular, was awarded the Santuario and Magallanes blocks. Another winning company was the Texas firm Schlumberger, which was awarded the Carrizo block near the city of Villahermosa.

That same year, PEMEX announced the results of a second round of bidding for Integrated Contracts for Exploration and Production. This time, it was for mature fields located in the northern regions of Veracruz and Tamaulipas in which 28 companies participated. Monclova Pirineos Gas and its Oleorey subsidiaries won the San Andres block, Petrolíferos de Tierra Blanca won the eponymous Tierra Blanca block, Petro SPM Integrated Services was awarded the Pánuco block, Petrofac Facilities Ltd. won the Arenque maritime contract area (near the cities of Tampico and Madero) and the Egyptian company Pico-Cheiron Ltd. won the Altamira block in Tamaulipas.

In 2013, a third round of bidding was held in which three of the six blocks offered by PEMEX in the Chicontepec area under the concept of Integrated Contracts for Exploration and Production of Crude Oil-Amatitlán,
Pitepec, and Miahuapan-were rendered null and void due to a lack of proposals. The remaining three blocks were allocated to Mexican subsidiaries of the U.S. companies Halliburton (Humapa) and Petrolite (Soledad) and the Mexican company Operadora de Campos DWF (Miquetla) (Petróleos Mexicanos 2013).

In December 2013, Mexico amended its constitution to allow both domestic and foreign private investment into the energy sector for the first time since its nationalization in 1938. The reforms now permit international energy companies to operate in Mexico and include provisions for competitive production-sharing contracts and licenses. On August 13, 2014, after the approval of the energy reform, the Secretariat of Energy presented three bidding processes for oil blocks, which were called rounds and identified as zero, one and 0.5. The first, Round Zero, stipulated that Pemex's initial assignment was to choose the fields where it wished to work, either on its own or in alliance with a private initiative.

Round 0.5 involved contracts that Pemex and its contractors had the possibility of migrating to the new contractual modalities of exploration and extraction; specifically, these were the Comprehensive Exploration and Production Contracts (CIEP, for its Spanish acronym) and the Funded Public Works Contracts (COPF, for its Spanish acronym). Round One was the opening of processes in which private initiatives could participate without needing to associate with Pemex in a bid for oil exploration and production contracts for hydrocarbons.

The first phase of Round One, Aguas Someras, tendered 14 exploration contracts, the allocation of which was scheduled for July 15, 2015. The second phase, in September 2015, was comprised of nine fields in five areas located in the shallow waters of the Gulf of Mexico. The third phase of Round One, which took place in December 2015, was made up of landfills for the extraction of hydrocarbons. The blocks were grouped into three geographic areas identified as Campos Burgos, Campos Norte, and Campos Sur. The fourth phase included ten areas located in the deep waters of the Gulf of Mexico between the Lost Belt and Salt Basin oil provinces.

Round Two also had four phases. The first was for shallow water, and it resulted in joint ventures between international oil companies that were entering into the Mexican oil market. Phases two and three were dedicated to land fields, and for the last-named 2.4-Mexico's National Hydrocarbons Commission reported the allocation of 19 of the 29 blocks in Perdido, Campeche and in the plains along the Gulf of Mexico.

In regard to Pemex's three rounds of integrated contracts, Clause 19.8 and Annex 18 address issues related to the impact of oil operations on communities and specify that each company that wins a tender must spend 
$1 \%$ of its annual operating expenses on CSR actions in these main three areas: environment, social development, and economic development. This type of contract gave contractors the freedom to specify the amount to be invested in contributions to sustainable development in the areas where they work (Fig. 1).

The Energy Reform did not contemplate this clause, but it established important changes in the diagnosis, execution, and development of the social development projects that must be carried out by oil companies (Articles 118 and 121 of the Hydrocarbons Law, as well as those related to Section 4, 117, and 120 of the Electrical Industry Law). In this sense, the new law establishes that the Secretariat of Energy is responsible for complying with sustainability principles and respecting communities and human rights in places where energy sector projects are to be developed. It must also comply with social impact and sustainable development provisions, as established by the regulations, in addition to carrying out a Social Impact Assessment and obtaining all legal authorizations. In this regard, it should be emphasized that creating Electric and Hydrocarbons Industry Law regulations has translated into significant changes in social impact studies.

The mandatory establishment of a social management program following a Social Impact Assessment went well beyond the activities covered by the Integrated Oil Exploration Contracts (CIEPS). This included areas such as shallow and deep waters exploration and production; terrestrial seismic exploration; oil treatment and refining; transportation and storage of hydrocarbons, petroleum, and petrochemicals; distribution and sale of natural gas and oil; the compression, liquefaction, decompression, and regasification of natural gas; and the generation of electric energy.

\section{Discussion and evaluation}

The establishment of the Electric and Hydrocarbons Industry Law regulations implied that social impact studies

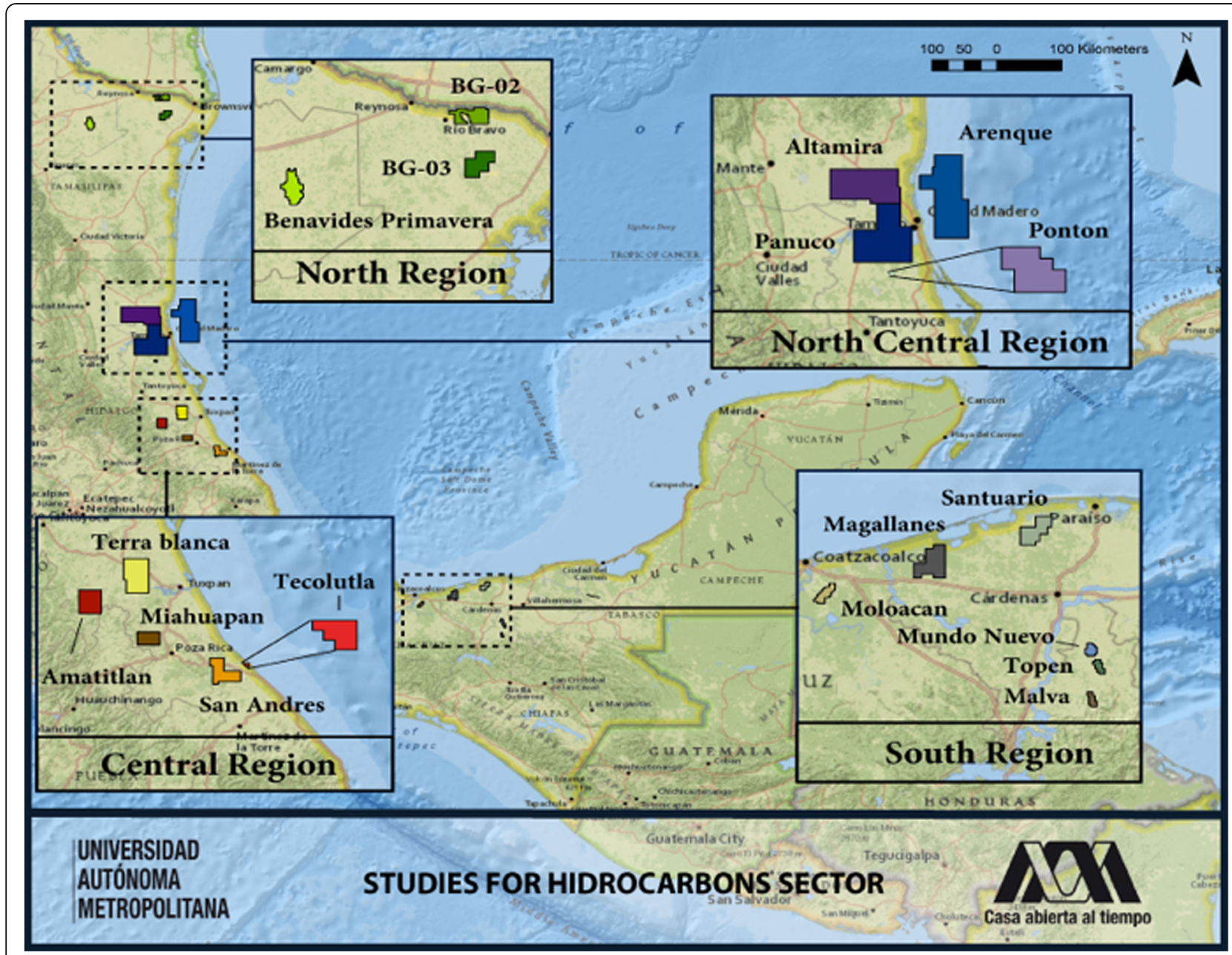

Fig. 1 Oil blocks where the UAMI's team has been working. Elaborated by Paul Fabre for UAMI's Team, 2018 
had become more complex, and it should be said, more complete. In the case of CIEPs, oil and gas companies were required to carry out a baseline socio-economic analysis along with initial environmental studies, establish CSR plans, and define proposals to encourage the social development of the populations living in these petroleum contractual areas. However, no specific format was required for these studies; each company was free to carry them out as they best saw fit.

It is in this context that, as of September 2012, a group of researchers from Universidad Autónoma Metropolitana, Unidad Iztapalapa (UAMI), in the framework of the project "Social and Environmental Aspects Related to the Oil Industry," developed nine baseline socio-economic studies that were the basis of CSR plans. Likewise, about 200 proposals for actions were developed with the objective of encouraging the development of the populations that live in these petroleum contractual areas.

In the second half of 2015, the team initiated a series of methodological changes in the baseline social studies while updating them and analyzing the impact of three oil companies' CSR actions. These methodological changes allowed for a relatively comfortable transition towards the establishment of Social Impact Assessments that fully complied with the requirements established by the National Hydrocarbons Commission and the Secretariat of Energy for the social diagnostic evaluation of oil companies that won the new biddings to independently exploit oil fields (García-Chiang and Hernández 2015).

The new Electric Industry Law and Hydrocarbons Law regulations implied the establishment of a Social Impact Assessment (SIA, named EvIS in Mexico) that was created in accordance with international parameters and developed into three formats, labeled A, B, and C. The first deals with selling gasoline to the public and generating electric energy up to $2.5 \mathrm{MW}$, and the second refers to storing gas and oil and generating electric energy up to $50 \mathrm{MW}$. The third format deals with more complex issues, including the oil blocks that private companies can exploit. Accordingly, a correct establishment of this kind of study and the implementation of adequately identified social development actions can contribute to local development.

The methodology developed by the team from Universidad Autónoma Metropolitana, Iztapalapa (UAMI) can be implemented in other petroleum-producing areas in the country and can also be applied to their operational instruments. This allows oil companies and even other public agents to execute proposals based on the proposed CSR, which improve the quality of life in the communities where oil is exploited. This methodological approach has a quantitative phase, which includes the baseline and its complements, and a qualitative phase, which includes interviews and surveys (García-Chiang 2012).
The methodological framework that initially guided the projects, with a methodology that is presented in this text, referenced the concept of a "territorialized actor." It should be noted that for Gumuchian et al. (2003), the territory is a scene in which representations unfold over several acts. Therefore, the actor is omnipresent, yet-from a geographical standpoint-he is not at the forefront (García-Chiang 2014). The following diagram shows the elements that the concept of a "territorialized actor" considers necessary for understanding a territory (Fig. 2).

Methodological integration enabled the creation of a "socio-territorial diagnosis," which was the basis for identifying areas of opportunity and CSR proposals focused on promoting local development by improving the living conditions of populations that are directly or indirectly affected by the oil industry. There are six steps: 1) Create a social baseline according to demographic, economic, educational, health, migratory, religious, and housing indicators as well as the availability of goods and other factors; 2) Analyze the socio-spatial impact of the oil industry by creating a geographic information system and designing mapping methodology based on choremes to show the highly territorial nature of this industry through the relationships between its elements (wells, batteries, pipelines, etc.) and the numerous population centers; 3) Conduct a socio-economic survey to identify social and economic factors that determine the needs, wants, and/or demands of the communities in oil areas; 4) Develop structured and semi-structured interviews with key social and institutional stakeholders in the study regions; 5) Create social matrices that designate and color-code different socioeconomic indicators according to the impact levels of oil operations in the territories; 6) Develop a CSR Plan that establishes guidelines for company actions in the field as well as proposals derived from the steps mentioned above.

Bestratén-Belloví and Pujol-Senovilla (2003) established a classification of social responsibilities taking key stakeholders, workers, and the community into account. The second classification these authors made is based on the differentiation of two levels-one within the company and one outside of it-with which they define primary, secondary, and tertiary responsibilities. Primary responsibilities are inherent to the company's specific activity. If the company neglects to ensure its proper operation by not attending to these responsibilities adequately, there could be severe consequences that could even affect the company's survival. Secondary responsibilities involve improving the effects of the same specific activity on interdependent social groups within the companies, and they always go beyond the required minimum. Finally, tertiary responsibilities extend to actions to 


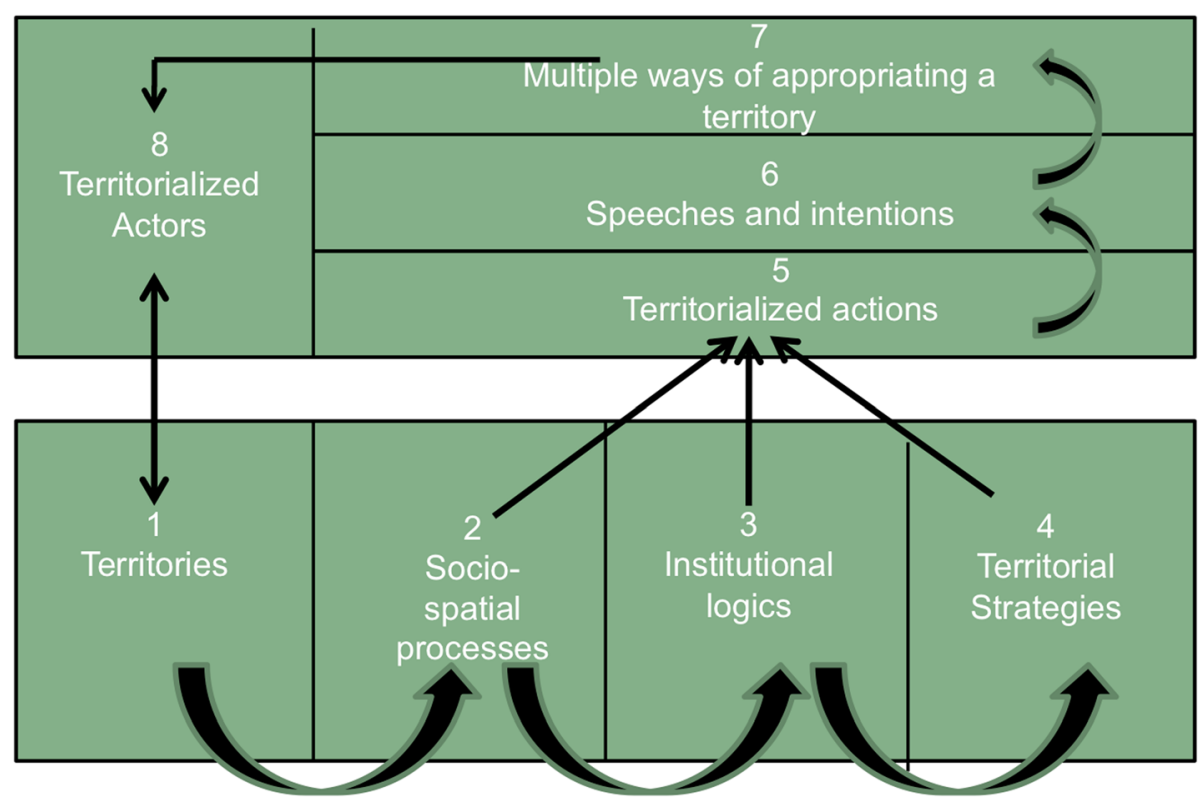

Fig. 2 Territorialized Actor Scheme (adapted from Gumuchian et al. (2003). Les acteurs, ces oublies du territoire. Paris:Anthropos)

improve certain aspects of their social environment beyond this specific activity.

Bestratén and Pujol believe it is necessary to comply with primary and secondary actions in order to achieve these tertiary actions, which incorporate activities in the community that are not directly related to the company's business. They argue that a company should first have proper internal conditions to then later be able to do something for the community in which it operates.

Primary actions are confined to the company's internal environment and exclude carrying out community action projects. The community can be incorporated in the secondary and tertiary actions. In secondary actions, which are directly related to a company's productive activity, it can, for example, facilitate employment and economic activity in the local community or county, providing advice and assistance to the community on matters stated therein and, where the company has knowledge and resources, collaborate in the creation of internships for vocational education and university students.

As for the tertiary activities, companies are contributing to improving the socio-cultural environment, working in different ways with vocational and business education centers in their spheres of influence, sponsoring or offering patronage of arts and cultural activities, or assisting groups in need (Bestratén-Belloví and PujolSenovilla 2003). Taking the above statements into account, we can infer that establishing different types of CSR actions reflects companies' need to ensure proper planning of strategic activities.
The experience gained through these technical assistance projects has led to a different classification of CSR actions that focuses on the relationships with the communities in which these companies work. One of its primary objectives is to facilitate operational continuity and be equipped for the secondary and tertiary activities mentioned in the paragraph above.

Level I: Agree on actions for community care, which are generally short-term and targeted at a focused segment of the population. For example: repairing school infrastructure. This level may be cyclic.

Goal 1: Establish a relationship between the company and the communities, seeking an immediate impact on the basic needs of the population while a first contact is established without hostilities. Additionally, aggressive actions that could potentially cause a poor first impression are avoided.

Level II: Carry out social support actions that affect a broad range of people in contractual areas in the short and medium term, or even sometimes in the long term. Goal 2: Integrate with the community. At this point, the evolution of actions should be channeled towards the extension of benefits to the general population, targeting elements such as medical services, building and/or remodeling of public spaces and family recreation facilities, and developing ecological sanitation.

The completion of civil works, execution times, and environmental and social impacts can cause some discomfort in communities, which may be even more difficult if 
there is no previous public knowledge of the company's modus operandi. Therefore, this is a medium and long-term level of action.

Level III: Actions seeking to influence local development within areas where the productive activity takes place. These are medium and long-term. They could be productive initiatives, problem-solving research in the company's sphere of influence, or proposed land use, among others.

\section{Conclusions}

The amount of money invested in Mexican oil blocks is relatively small, but it should be noted that each contractual area is between 300 and $1,000 \mathrm{~km}^{2}$. It should also be noted that one of the recurring criticisms of CSR is that the actions have no real impact on local development since they generally focus on doing visible works within a relatively low budget, such as remodeling schools or donating medical supplies.

In this regard, we stress that companies that are able to create cooperative relationships with communities and local governments may be able to build a more stable environment for their operations. This necessarily implies a vision that goes beyond philanthropy and donations, as these actions only bring temporary benefits, and in the long term, they may be harmful to social stability and the management of local expectations. However, there's a high risk involved in merely painting over the surface of problems, and businesses that have this practice may fall into ill repute. It is possible that CSR is going through a transition stage where theory and practice must be developed symmetrically because, despite the existence of tools and application systems, it is essential to avoid reducing it to a merely aesthetic discourse. It is also necessary to keep its ethical foundations in mind.

From our point of view, and as mentioned above, there are two essential conditions for actually achieving results for local development by investing in communities within the context of CSR actions in oil-production regions. The first of these conditions is a 'territorialization' of the proposals, and the second is the creation of different types of CSR actions.

Currently, the integrated contracts are concluding their two-year trial period. Consequently, there have been many responses need to present the CSR actions to communities immediately. This has led to giving priority to Level I actions which, it must be accepted, have little impact on community development. At the end of a company's trial period, it reaches an agreement with Pemex about whether or not to continue for the duration of the contract. This period, ranging from 25 to 30 years, will be an opportunity to prove that CSR can be a source of funding for development. In this context, CSR actions should be more ambitious. The short term should not be prioritized, and projects and programs should be promoted in a way that can truly contribute to local development.

\begin{abstract}
Abbreviations
CELAC: Community of Latin American and Caribbean States; CFE: Comisión Federal de Electricidad; CIEP: Integral Oil Exploration Contracts;

CIEP: Integrated Petroleum Exploitation Contract; CSR: Corporate Social Responsibility; EU-LAC: European Union-Latin American Countries; GRI: Global Reporting Initiative; OECD: Organization for Economic Co-operation and Development; PEMEX: Petróleos Mexicanos; RMNE: Northeast Marine Region; RMSE: South Marine Region; S.A de C.V: Limited Company of Variable Capital; SIA: Social Impact Assessment; SMEs: Small and Medium-Sized Enterprises; UAMI: Universidad Autónoma Metropolitana, Iztapalapa
\end{abstract}

\section{Acknowledgements}

I wish to thank the Technical Staff of the Research project Social and Environmental Aspects Related to the Oil Industry, for all the work that has made possible the realization of more than 30 technical assistance projects. I also wish to thank the Support staff of the Department of Sociology, Universidad Autónoma Metropolitana, Unidad Iztapalapa, México for all the administrative work that has made possible the realization of the projects.

Funding

Cologne Business School (CBS) through a SpringerOpen Membership.

Availability of data and materials

All the materials and data are promptly available to readers.

\section{Author's contribution}

The conception and design, and/ the analysis and interpretation of data are from author AGC. Likewise, the drafting of the article is the responsibility of the author who give final approval of the version to be submitted and any revised version.

\section{Authors' information}

Geographer and Sociologist with more than ten years of experience in the field of the local development and CSR. I have a bachelor's degree in Geography from the National University of Mexico (UNAM), a Master in Regional Studies from the Research Institute Dr. José María Luis Mora and a Ph.D in Sociology from the Ecole des Hautes Études en Sciences Sociales, Paris.

Actually I am a Full time Professor at the Universidad Autónoma Metroploitana, Unit Iztapalapa, Mexico City.

Among my key qualifications, I want to stand out:

- In depth-experience in rural community-based development (France

2002,2003; Mexico 2000-2008, 1991-1996),

- Comprehensive approach of the social corporate responsibility that includes practical application and teaching

- In depth-experience in Social Impact Assessment (Mexico 2006-2018),

- Practical experience with indigenous communities (1985-2002),

- Sound experience in alternative rural production and commercialization (Mexico, 1991-1995, France 2005)

- Practical experience in Human Rights issues (Chiapas Mexico, 1985-1995),

- Appraise in the field of the sustainable development, design of

methodologies of analysis, strategic planning

\section{Competing interests}

"The author Armando García Chiang declare that he have no competing interests".

\section{Publisher's Note}

Springer Nature remains neutral with regard to jurisdictional claims in published maps and institutional affiliations.

Received: 19 March 2018 Accepted: 10 September 2018

Published online: 30 November 2018

\section{References}

Bestratén-Belloví, M., \& Pujol-Senovilla, L. (2003). Responsabilidad social de las empresas (II): Tipos de responsabilidades y plan de actuación. España: Ministerio 
de Trabajo y Asuntos Sociales/ Instituto Nacional de Seguridad e Higiene en el Trabajo.

Dauzacker, N. (2007). Environmental impact: Recognition and management accounting (doctoral thesis). Argentina: National University of Rosario.

Flores, R. (2009). Impacto de la responsabilidad social empresarial en los negocios vinculados a petróleo y gas (Tesis de maestría no publicada). Buenos Aires: Universidad Tecnológica Nacional.

Frynas, J. (2009). Beyond corporate social responsibility. Oil multinationals and social challenges. Cambridge: Cambridge University Press.

García-Chiang, A. (2012). El diagnóstico social en la industria petrolera. Propuesta metodológica para elaborar un Plan de Responsabilidad Social. Equilibrio Económico, Revista de Economía, Política y Sociedad, 8(34), 203.

García-Chiang, A. (2014). La territorialización en el análisis sociológico. En H. J. Suárez y K. Pirken (coords.), Los sociólogos y su sociología (p. 267-326). México: Instituto de Investigaciones Sociales/ UNAM.

García-Chiang, A., \& Hernández, A. (2015). Responsabilidad social, sustentabilidad y desarrollo local: estudios de línea de base social como propuesta metodológica para el diagnóstico social en la industria petrolera. Investigación y Gestión Oganizacional, 2(1), 7-27.

García-Chiang, A., \& Rodríguez, J. (2008). Responsabilidad Social en la empresa. La región Marina noreste de Pemex Exploración y Producción. Equilibrio Económico, IX, 4(1), 17-40.

Garriga, E., \& Melé, D. (2004). Corporate social responsibility theories: Mapping the territory. J Bus Ethics, 53(1-2), 51-71.

Grayson, G. (1980). The politics of Mexican oil. Pittsburgh: University of Pittsburgh Press.

Gumuchian, H., Grasset, E., Lajarge, R., \& Roux, E. (2003). Les acteurs, ces oublies du territoire. Paris: Anthropos.

Pemex Exploración y Producción. (2012). Modelo de Contrato para Producción de Hidrocarburos en el área contractual. México: PEMEX.

Pérez, M. (2009). Responsabilidad Social Corporativa y comunicación: la agenda de las grandes empresas mexicanas. Signo y pensamiento, XXVIII(55), 201-217.

Petróleos Mexicanos. (2002). Informe Anual 2002, Seguridad, Salud y medio ambiente. México: Dirección Corporativa de Seguridad Industrial y Protección Ambiental/ PEMEX

Petróleos Mexicanos. (2006). Código de Conducta. México: PEMEX.

Petróleos Mexicanos. (2013). About integrated EP contract. México: PEMEX.

\section{Submit your manuscript to a SpringerOpen ${ }^{\circ}$ journal and benefit from:}

- Convenient online submission

- Rigorous peer review

- Open access: articles freely available online

High visibility within the field

- Retaining the copyright to your article

Submit your next manuscript at $\boldsymbol{\nabla}$ springeropen.com 